\title{
MULTIANNUAL BUDGETARY FRAMEWORKS IN THE RUSSIAN FEDERATION
}

The basis of multiannual financial planning was laid in the Russian Federation by the Concept of budget process reforming in the Russian Federation (hereinafter 'Concept') in 2004-2006, approved by the Government of the Russian Federation'.

Earlier, in the post-Soviet period, budget planning had other approaches.

By the beginning of the reform, Russian budget law provided for neither multiannual budget planning or estimation of budget expenditure results, resulting in the following:

- mid-term financial plans were developed for the annual budget cycle only; budget expenditure was planned just for the next year. Budget legislation did not define sums or the structure of budget appropriations allocated to budget administrators;

- budget expenditures were calculated by adjusting (indexing) the recent year expenditures. The Budget Code of the Russian Federation did not prescribe mechanisms of budget resource redistribution. We did not have clear criteria and procedures for the selection of areas to which funds were to be directed in accordance with the priorities of state policy;

- there was no clear formulation of budget expenditure objectives as well as criteria for estimating budget administrator results.

The main purpose of the Concept was the introduction of conditions for achieving the most efficient management of the state (municipal) funds in accordance with the priorities of state policy. The essence of the reform was to shift the budget process from the "management of budgetary resources (expenditures)" to the "management of results"; and to enhance responsibility and expand the independence of budget administrators within the framework of medium-term objectives.

1 The Decision of the Government of the Russian Federation of 22 May 2004 № 249 on measures to increase effectiveness of budget expenditures. 
The Russian authorities offered the following directions for the reform:

- to reform the budget classification of the Russian Federation and fiscal accounting procedure in accordance with international financial reporting standards;

- to divide the budget into existing obligations and accepting obligations;

- to improve medium-term financial planning;

- to introduce performance budgeting;

- to streamline procedures for drafting and adopting budget law.

The core of the new organization of the budget process should be the concept of "performance budgeting in the medium-term financial planning" widely used in the world. In other words, the main purpose was to increase the horizon of financial planning and to introduce program-objective methods of budget planning.

Some guidelines of the reform were based on international experience of budget reforms. According to the Russian financial authorities, a number of budgetary and legal institutions were affected by international standards adopted by the International Monetary Fund, the World Bank and the Organization for Economic Co-operation and Development ${ }^{2}$. In relation to the introduction of multi-annual financial planning and performance budgeting the Concept stated that one of the main elements of budget reforms undertaken in the last decade in most developed countries was the transition to medium-term budget planning. A budget cycle begins with a review of the approvals given in the previous budget cycle main parameters of the mediumterm financial plan, with analysis of changes in external factors and conditions, with substantiation of changes in the main budget indicators of the planned year as well as updating the budgetary projections for the next years of the forecast period.

The authors of the reform proposed introducing this approach into the Russian practice of budget planning. The budget for the next fiscal year should become a part of the mid-term (three year) plan that was annually updated. On the one hand, this system ensures the continuity of state policy and the predictability of budget allocations; on the other hand, it allows making transparent annual adjustments in accordance with policy objectives and the conditions of their achievements.

The purposes of the reform were to be implemented in stages. Firstly, the Russian authorities initiated transition to the multiannual budget. The Federal budget for 2006 became the first budget formed within the three-year financial plan. It was the basis for the drafting of fiscal policy for the next three-year budget.

Budget legislation provided for the transition to drawing up a three-year budget in 2007, when the Parliament of the Russian Federation amended the Budget Code. The amendments to the Budget Code provided for the annual drafting and adoption of 
the federal budget for 3 years (the next financial year and two-year planned period). That rule should ensure continuity and predictability of fiscal policy, contribute to the sustainability of the budget system of the Russian Federation, improve the reliability of budget expenditures, and make the state contracts for 3 years or for the whole period of implementation of long-term objective programs (investment projects).

The basis of budget planning consisted of the method of "sliding three-year budgeting". In such conditions, earlier adopted budget expenditures for second and third years of the three-year period become the basis of the next year budget. Actually, the Russian budget legislation reflected provisions adopted in Art. 9 of the Council of the European Union Directive 2011/85/UE of 8 November 2011 on requirements for the budgetary frameworks of Member States that prescribes providing for the adoption of a fiscal planning horizon of at least 3 years.

Adopting projections for the second and third years of the planned period did not mean a ban on their adjustment in the next budget cycle. However, these changes should not worsen the position of the main budget administrators and recipients of budgetary transfers. These provisions of Russian budget legislation meet Art. 9 (2b) of the Directive 2011/85/UE which prescribes that medium-term budgetary frameworks shall include procedures for establishing projections of each major expenditure and revenue item of the general government - for the budget year and beyond, based on unchanged policies.

Thus, "sliding three-year budgeting" philosophy ensures, on the one hand, the stability and predictability of the budgetary projections and, on the other, the possibility of their amendment in case of changes, restructuring expenditures, or the implementation of new priorities of budget policy.

In order to increase budget sustainability the Budget Code introduced "conditionally adopted expenditures" (5 percent of the total expenditure) that was not distributed among main budget administrators and articles of budget classification for the planned period (second and third years of the three-year period). These rules allowed to create a reserve fund to meet any unexpected decline of income or to be used for making new obligations in the next budget cycle.

The "sliding three-year budgeting" rules were indispensable but apply only to the federal budget. Regional and local authorities of the Russian Federation have the choice between adopting their budgets for 3 years or for just the next financial year (with the drafting of a mid-term financial plan).

The implementation of performance budgeting was more problematic.

Earlier Russian budget legislation provided for line-item budgeting. Financial authorities drafted budgets by indexing the previous year's budget expenditure. There were no estimations of budget expenditure effects.

To meet the requirements of the reform, the main instruments of budget planning should be federal objective programs and departmental objective programs. 
The federal objective programs had an inter-sectoral nature. They should be adopted by the Government of the Russian Federation and should provision for large investment projects (scientific-technical and/or structural) requiring a long period of realization. Departmental objective programs are intra-sectoral and are adopted by special executive authorities.

The Budget Code of the Russian Federation provided for these types of programs. They were used in the budget planning. However, currently, the federal objective program was renamed into the state program of the Russian Federation.

Nowadays, the state programs should, in particular, contain the objectives and priorities of state policy; the list and characteristics of the main activities to achieve state program objectives with timelines for their implementation and expected results; the main measures of the legal regulation aimed at achieving the objectives and/or the expected results of the state program; as well as information on objective indicators of the state program broken down by years of its implementation, information about financial provision of the state program funded by the federal budget (details by the main budget administrators, by federal objective programs and by the years of the state program implementation).

At the present time, the Government of the Russian Federation has adopted the Procedure for development, implementation and estimation of effectiveness for state programs of the Russian Federation ${ }^{3}$, the List of state programs of the Russian Federation ${ }^{4}$. The Ministry of Economic development and the Ministry of Finance have approved the methodological recommendations for the development and implementation of state programs of the Russian Federation ${ }^{5}$. In 2012-2013, the Government of the Russian Federation adopted 39 state programs.

The law on federal budget for 2014 and for the planning period of 2015 and 2016 became the first budget approved in the context of state programs. It contains an exhibit that breaks down expenditures by state programs.

Nowadays performance budgeting is implemented at the regional level with methodical support of the Ministry of Finance. By the beginning of 2013, 45 subjects of the Russian Federation adopted statutory legal acts on the procedure of development and implementation of regional state programs.

Despite the gradual implementation of multi-annual financial planning and performance budgeting in Russian budget law the reforms are continuing.

The President of the Russian Federation drew attention to the fact that the planning of socio-economic development and budget planning still remain insufficiently coordinated. The tasks of socio-economic policy and the results of their implementation are still considered separately from the budget policy. There is

\footnotetext{
The Decision of the Government of the Russian Federation of 2 August 2010 № 588.

The Decision of the Government of the Russian Federation of 11 November 2010 № 1950-R.

The order of the Ministry of economic development of the Russian Federation and the Ministry of Finance of the Russian Federation of 26 December 2012 № 27.
} 
no clear system for estimating budget expenditure effectiveness. The state programs did not become a means for the formulation and implementation of state policy in the long-term. Many programs seek to increase budgetary financing without identifying financial sources. Some programs have been adopted in several variants that differ both on planned results and amounts of funding. The task of transition to long-term budget planning is not solved. The Government of the Russian Federation has not approved long-term budget strategy that should determine the cost framework of state programs in relation to the forecast of main budget parameters ${ }^{6}$.

The Program of the Government of the Russian Federation on increase of budgetary expenditure efficiency for the period until 2012, ${ }^{7}$ drew attention to the fact that strategic planning remained poorly linked with budget planning. In this regard, one of the main tasks was to draft mechanisms aimed at ensuring better integration of strategic and budget planning as well as monitoring the achievement of stated objectives.

Actually, in the Program Russian authorities took into account the provisions of documents adopted by international organizations. For example, according to Art. 2.1.2 of the Code of Good Practices on Fiscal Transparency $(2007)^{8}$ the annual budget should be realistic, and should be prepared and presented within a comprehensive medium-term macroeconomic and fiscal policy framework. Fiscal targets and any fiscal rules should be clearly stated and explained. In fact these tasks were prescribed by the mentioned Program.

Last year the Government of the Russian Federation adopted the Program for increase of public (state and municipal) finances management efficiency for the period until 2018. The Program shows that some problems remain unsolved in budget planning, including:

- the absence of regulatory procedures for drafting, studying and use of socioeconomic development forecasts in the budgetary process and in the drafting of state strategic planning documents;

- despite the program structure of the federal budget for the year 2014 and for the planning periods of 2015 and 2016, the Government of the Russian Federation did not take into account the achievement of state program objectives in the planning of budget appropriations. The issue of state program efficiency is not essential when drafting the federal budget;

- the absence of an integral system of strategic planning and weak linkage between strategic planning and budget planning;

6 The Budget message to the Federal Assembly of the Russian Federation of 13 June 2013 "On budget policy in $2014-2016 "$

7 The Decision of the Government of the Russian Federation of 30 June 2010 № 1101-R.

8 Approved by The international Monetary Fund in 2007.

9 The Decision of the Government of the Russian Federation of 30 December 2013 № 2593-R. 
- an uncertain relationship and lack of coordination between various objective program means;

- the incompleteness of formation and limited practice of state (municipal) programs as the main instrument to achieve the objectives of the public (municipal) policy as well as the basis for budget planning.

The Program suggests the following solutions:

1) to define all directions of the state (municipal) policy but only within the framework of state (municipal) programs. At the same time, strategic planning documents should define the main directions of the policy as well as requirements for the state (municipal) programs;

2) to draft the Budgetary strategy of the Russian Federation for the period until 2030 that should determine budget expenditure for the state programs on the basis of main budget parameter forecasts. The President of the Russian Federation prescribes to the Government of the Russian Federation to complete the development of the budgetary strategy of the Russian Federation for the period up to 2030 within a short timeframe as well as to amend the long-term forecast of socio-economic development if it is necessary ${ }^{10}$. This suggestion meets the requirements of Art. 9(3) of Directive 2011/85/UE which requires that projections adopted within medium-term budgetary frameworks shall be based on realistic macroeconomic and budgetary forecasts.

Russian scientists express the same opinion. They say that the problems related to performance budgeting are due to the objectives of budget expenditures being formulated outside the budget process in the course of budget administrator activity. In addition, detailed plans of economic and socio-economic development (national economic plans - three years, five years, and others) are not published.

The mechanism of drawing up such plans in the Russian Federation was lost with the dissolution of the USSR and the State Planning Committee of the USSR ${ }^{11}$.

By now, the Ministry of Economic development of the Russian Federation has adopted the forecast of long-term socio-economic development for the period up to 2030. Based on this document in accordance with the requirements of the Budget Code, the Ministry of Economic development drafts a forecast of socio-economic development of the Russian Federation for the next financial year and following twoyear planning period. In turn, this forecast becomes the economic basis for drafting

10 The Budget message to the Federal Assembly of the Russian Federation of 13 June 2013 "On budget policy in 2014 - 2016".

11 Komyagin D.L. The Budget Law of the Russian Federation: textbook / edited by A.N. Kozyrin. Moscow: The Institution of public law researches, 2011 (Комягин Д.Л. Бюджетное право России: учебное пособие / под ред. А.Н. Козырина. М.: Институт публично-правовых исследований, 2011). 
the budget for the next financial year and its following two-year planning period. In addition, the Government of the Russian Federation has adopted the Concept of long-term socio-economic development of the Russian Federation for the period up to $2020^{12}$.

Thus, in the last decade, the Russian Federation has taken serious steps in the transition to medium-term financial planning on the basis of performance budgeting. The federal budget is adopted for the next financial year and two-year planning period, broken down into state programs. However, there are problems related to correlation between mid-term financial planning and socio-economic planning, to estimation of program implementation. These problems should be solved by continuing reforms in the financial sector.

12 The Decision of the Government of the Russian Federation of 17 November 2008 № 1662-R (amended at 8 August 2009). 


\section{WIELOLETNIE RAMY BUDŻETOWE W FEDERACJI ROSYJSKIEJ}

W latach 2006-2007 rozpoczęto wprowadzanie w Rosji wieloletniego planowania finansowego. Od 2010 r. wprowadza się natomiast elementy budżetowania zadaniowego. Budżet federalny jest przyjmowany aktualnie na następny rok budżetowy i dwa lata okresu planowania z podziałem na programy państwowe. Jednocześnie nierozwiązane zostały problemy związane z korelacją między średniookresowym planowaniem finansowym i planowaniem społeczno-gospodarczym, do oceny realizacji programu. Te problemy powinny być rozwiązywane przez kontynuację reform w zakresie sektora finansowego.

Słowa kluczowe: budżet zadaniowy, średnioterminowe planowanie finansowe, wydatki budżetowe, program celowy

Keywords: performance budgeting, medium-term financial planning, budget expenditure, objective program 